\title{
Influence of different transplanting date and weed management practices on yield and quality of basmati rice (Pusa Basmati-1509)
}

\author{
Vikram Kumar $^{1 *}$, V.S. Hooda ${ }^{1}$, D. P. Nandal ${ }^{1}$, Sunil Kumar ${ }^{2}$ and Gaurendra Gupta ${ }^{3}$ \\ ${ }^{1}$ Department of Agronomy, CCS Haryana Agricultural University, Hisar-125004 (Haryana), INDIA \\ ${ }^{2}$ Department of Agronomy, Institute of Agricultural Sciences, Banaras Hindu University, Varanasi (UP), INDIA \\ ${ }^{3}$ Division of Agronomy, Indian Agricultural Research Institute, New Delhi, INDIA \\ *Corresponding author. E-mail: vikgadi@gmail.com
}

Received: September 11, 2016; Revised received: April 21, 2017; Accepted: September 12, 2017

\begin{abstract}
A field experiment was conducted during kharif 2014 at students' farm of Chaudhary Charan Singh Haryana Agricultural University, college of agriculture, Kaul (Kaithal). The experiment consisted of four transplanting dates (June 15, July 5, July 25 and August 15) in main plots and six weed control treatments in sub plots treatments consisted of pre-emergence application of pretilachlor, oxadiargyl alone and sequential application of pre and post emergence herbicides viz., pretilachlor $f b$ bispyribac, oxadiargyl fb bispyribac, weed free check and unweeded check. Based on research investigation it was observed that early transplanting dates (June 15 and July 5) produced taller plant, higher tillers $/ \mathrm{m}^{2}$ and crop dry matter accumulation at all growth stages. Early transplanting produced significantly higher number of effective tillers $/ \mathrm{m}^{2}(263)$ along with higher number of filled grain/ panicle (85) than delayed planting (July 25 and August 15). The 1000-grain weight was not affected by time of transplanting. The highest grain yield $(4363 \mathrm{~kg} / \mathrm{ha}$ ) was recorded under June 15 transplanting which was statistically at par to the grain yield $(4058 \mathrm{~kg} / \mathrm{ha}$ ) obtained under July 5 transplanting. Among the weed management practices tried, weed free check resulted in the highest values of plant height $(104.2 \mathrm{~cm})$, tillers $/ \mathrm{m}^{2}(305)$, crop dry matter accumulation (964 $\mathrm{g} /$ $\left.\mathrm{m}^{2}\right)$, effective tillers $/ \mathrm{m}^{2}(271)$, grains length $(8.5 \mathrm{~cm})$, filled grains/panicle $(86.3)$ as well as grain $(4516 \mathrm{~kg} / \mathrm{ha})$ and straw yield $(5506 \mathrm{~kg} / \mathrm{ha})$ which were however, comparable to pre-emergence application of oxadiargyl followed by bispyribac-sodium applied at 25 DAT and pretilachlor followed by bispribac-sodium at 25DAT.
\end{abstract}

Keywords: Bispyribac, Oxadiargyl, Pretilachlor, Quality, Transplanting date

\section{INTRODUCTION}

Rice is the most important cereal food crop of the world providing major source of the food energy for more than half of the human population. India is the second largest producer of rice in the world with production of 106 million tonnes from 43.50 million hectares, with a productivity of 2.41 tonnes/ha during the year 2013 (Anonymous, 2014a). In Haryana, rice occupies an area of 1.2 million hectares with production and productivity of 3.99 million tonnes and $3256 \mathrm{~kg} /$ ha, respectively (Anonymous, 2014b).

The profitability in terms of yield and quality is governed by selection of varieties and management practices. Timely planting of basmati rice is an important factor in determining grain yield and quality parameters. Time of transplanting may be one of the agronomic strategies to exploit full potential of a variety and its photoperiod sensitivity so as to harness maximum production with improved quality of grain for high premiums. Selection of proper variety, suitable to the specific ecological situation, may prove to be a boom to the farmers. The traditional varieties of scented rice grown in Haryana are tall and prone to lodging particularly when a higher dose of nitrogen is applied. Therefore, growing suitable dwarf varieties of scented rice with higher yield and acceptable quality is important to increase the production of basmati rice (Sharma et al., 2008).

Weeds pose major problem in rice production, by diminishing the quantity as well as quality (Rajkhowa et al, 2007). Hence, the weed management plays an important role in increasing productivity of rice. Hand weeding is effective and the most common method to control weeds. However, it is laborious and tedious in rice growing areas due to increase in labour cost and non-availability of labour during peak periods of other agricultural operations. The use of herbicides offers scope for economical control of weeds right from the beginning. Recent trend of herbicide use is to find out, an effective weed control measure by using low dose high efficiency herbicides which will not only reduce the total volume of herbicide/unit area, but also the application becomes easier and economical to the farmer (Subramanyam et al., 2007).

\section{MATERIALS AND METHODS}

The present field experiment was conducted during 
kharif 2014 at student's farm of CCSHAU, college of agriculture, Kaul (Kaithal), Hisar ( latitude $29^{\circ} 51^{\prime} \mathrm{N}$, longitude $76^{\circ} 41^{\prime} \mathrm{E}$ and altitude 241 metres above mean sea level ). The soil of the experimental field was clay loam in texture, low in organic carbon, low in available nitrogen, medium in phosphorus, high in potash and alkaline in nature.

The experiment was laid out in a split plot design with 4 main plot treatments and 6 sub plot treatments with replicated thrice. The main plot having date of transplanting which were $15^{\text {th }}$ June, $5^{\text {th }}$ July, $25^{\text {th }}$ July and $15^{\text {th }}$ August. In sub plot plot treatments consisted of pre-emergence application of pretilachlor $1000 \mathrm{~g} / \mathrm{ha}$, oxadiargyl $100 \mathrm{~g} / \mathrm{ha}$ alone and sequential application of pre- and post emergence herbicides viz., pretilachlor $1000 \mathrm{~g} /$ ha+bispyribac $25 \mathrm{~g} / \mathrm{ha}$, oxadiargyl $100 \mathrm{~g} /$ ha+bispyribac $25 \mathrm{~g} /$ ha, weed free check and unweeded check. The required quantities of pre- and postemergence herbicides were applied uniformly at 4 and 25 DAT, respectively. The crop was raised according to package of practices of CCSHAU, Hisar. Onemonth-old nursery of well adapted high yielding coarse rice variety Pusa Basmati-1509 was transplanted at a hill spacing of $20 \times 15 \mathrm{~cm}$, therefore, plant population was 33 hills $/ \mathrm{m}^{2}$ for all the treatments. Data were recorded on different agronomic parameters including growth parameter, yield parameter and quality parameter. The data were analyzed statistically using analysis of variance technique and significant means were separated using least significance difference test for comparing the treatment means (Steel and Torrie, 1980).

\section{RESULTS AND DISCUSSION}

Growth parameters: Plant height increased with advancement in crop age up to 90 DAT (days after transplanting). The highest increase in plant height was observed between 30 and 60 DAT and minimum increase from 60 to 90 DAT. Crop planted on June 15 $(104.9 \mathrm{~cm})$ caused a significantly better height than all of the delayed transplanting dates except July 5 (102.8 $\mathrm{cm}$ ) which was statistically at par to the earlier. Among the weed control treatments, weed free plots recorded significantly taller plants at harvest $(104.2 \mathrm{~cm})$ which were at par to that recorded with application of oxadiargyl followed by bispyribac-sodium $(101.7 \mathrm{~cm})$ and pretilachlor followed by bispyribac-sodium (101.2 $\mathrm{cm})$. Time of transplanting had significant effect number of tillers $/ \mathrm{m}^{2}$ at all the stages of crop growth. The crop planted on June $15\left(301 / \mathrm{m}^{2}\right)$ which was statistically at par to July $5\left(275 / \mathrm{m}^{2}\right)$ planting, produced significantly higher number of tillers than delayed planting (July 25 and August 15). Among different weed control treatments, weed free $\left(305 / \mathrm{m}^{2}\right)$ recorded significantly highest number of tillers $/ \mathrm{m}^{2}$ which was statistically similar to application of oxadiargyl followed by bispyribac-sodium $\left(301 / \mathrm{m}^{2}\right)$ and pretilachlor followed by bispyribac-sodium $\left(289 / \mathrm{m}^{2}\right)$. The dry matter accumulation increased with advancement of crop age. The highest increase in dry matter was observed between 30 and 60 DAT. Time of transplanting had significant effect on dry matter accumulation by the crop at different stages of crop growth. At all the crop growth stages, crop planted on June $15\left(952 \mathrm{~g} / \mathrm{m}^{2}\right)$ which was sta-

Table 1. Effect of different transplanting dates and weed management practices on yield attributing characters in Kharif 2014.

\begin{tabular}{|c|c|c|c|c|c|c|c|}
\hline Treatments & $\begin{array}{l}\text { Plant } \\
\text { height } \\
(\mathrm{cm}) \\
\end{array}$ & $\begin{array}{l}\text { Number } \\
\text { of till- } \\
\text { ers } / \mathbf{m}^{2}\end{array}$ & $\begin{array}{l}\text { Crop dry mat- } \\
\text { ter accumula- } \\
\text { tion }\left(\mathrm{g} / \mathrm{m}^{2}\right)\end{array}$ & $\begin{array}{l}\text { No. of filled } \\
\text { grains/ } \\
\text { panicle }\end{array}$ & $\begin{array}{l}\text { No. of un- } \\
\text { filled grains/ } \\
\text { panicle }\end{array}$ & $\begin{array}{l}\text { 1000- } \\
\text { grain }\end{array}$ & $\begin{array}{l}\text { Effective } \\
\text { tillers } / \mathbf{m}^{2}\end{array}$ \\
\hline \multicolumn{8}{|c|}{ Main plot (transplanting dates) } \\
\hline 15-Jun & 104.9 & 301 & 952 & 85 & 9.6 & 28.4 & 263 \\
\hline 05-Jul & 102.8 & 275 & 871 & 79.3 & 10.6 & 27.4 & 245 \\
\hline 25-Jul & 97.6 & 261 & 827 & 76.6 & 11.7 & 26.8 & 237 \\
\hline 15-Aug & 92 & 236 & 748 & 64.3 & 17.8 & 26.3 & 199 \\
\hline $\mathrm{SEm} \pm$ & 1.7 & 7 & 24 & 2.1 & 0.3 & 0.4 & 6 \\
\hline $\mathrm{CD}$ at $5 \%$ & 6 & 26 & 84 & 7.5 & 1.1 & NS & 23 \\
\hline \multicolumn{8}{|c|}{ Sub plot (weed control treatments) } \\
\hline $\begin{array}{l}\text { Oxadiargyl } 100 \mathrm{~g} / \mathrm{ha} \\
(\mathrm{PE})\end{array}$ & 100 & 262 & 828 & 74.3 & 13.1 & 27.2 & 228 \\
\hline $\begin{array}{l}\text { Pretilachlor } 1000 \mathrm{~g} / \mathrm{ha} \\
(\mathrm{PE})\end{array}$ & 99.6 & 239 & 756 & 67.4 & 14.6 & 26 & 208 \\
\hline $\begin{array}{l}\text { Oxadiargyl } 100 \mathrm{~g} / \mathrm{ha} \\
(\mathrm{PE}) \mathrm{fb} \text { bispyribac-Na } \\
25 \mathrm{~g} / \mathrm{ha}(25 \mathrm{DAT})\end{array}$ & 101.7 & 301 & 953 & 85.5 & 10.7 & 27.5 & 262 \\
\hline $\begin{array}{l}\text { Pretilachlor } 1000 \mathrm{~g} / \mathrm{ha} \\
(\mathrm{PE}) \mathrm{fb} \text { bispyribac-Na } \\
25 \mathrm{~g} / \mathrm{ha}(25 \mathrm{DAT})\end{array}$ & 101.2 & 289 & 914 & 82 & 11.7 & 27.3 & 258 \\
\hline Weed free & 104.2 & 305 & 964 & 86.3 & 10.4 & 28.2 & 271 \\
\hline Weedy & 94.7 & 216 & 684 & 61.6 & 16.6 & 25 & 189 \\
\hline $\mathrm{SEm} \pm$ & 1.2 & 6 & 18 & 1.6 & 0.5 & 0.3 & 5 \\
\hline $\mathrm{CD}$ at $5 \%$ & 3.6 & 17 & 52 & 4.6 & 1.3 & 0.9 & 14 \\
\hline
\end{tabular}


Table 2. Effect of different transplanting dates and weed management practices on yield and quality parameters in Kharif 2014.

\begin{tabular}{|c|c|c|c|c|c|c|}
\hline Treatments & $\begin{array}{l}\text { Grain yield } \\
(\mathrm{kg} / \mathrm{ha})\end{array}$ & $\begin{array}{l}\text { Straw yield } \\
(\mathrm{kg} / \mathrm{ha})\end{array}$ & $\begin{array}{l}\text { Hulling } \\
\text { percentage }\end{array}$ & $\begin{array}{l}\text { Grain } \\
\text { length } \\
(\mathrm{mm})\end{array}$ & $\begin{array}{l}\text { Length- } \\
\text { breadth } \\
\text { ratio } \\
\end{array}$ & $\begin{array}{l}\text { Benefit } \\
\text { and Cost } \\
\text { Ratio }\end{array}$ \\
\hline \multicolumn{7}{|l|}{ Main plot (transplanting dates) } \\
\hline 15-Jun & 4346 & 5485 & 76.8 & 8.3 & 4.9 & 1.43 \\
\hline 05-Jul & 4058 & 5021 & 77.4 & 8.2 & 4.9 & 1.34 \\
\hline 25-Jul & 3918 & 4768 & 78.2 & 8.1 & 4.8 & 1.29 \\
\hline 15-Aug & 3289 & 4108 & 80 & 8 & 4.7 & 1.1 \\
\hline $\mathrm{SEm} \pm$ & 109 & 137 & 0.7 & 0.1 & 0.05 & \\
\hline $\mathrm{CD}$ at $5 \%$ & 383 & 484 & NS & NS & NS & \\
\hline \multicolumn{7}{|l|}{ Sub plot (weed control treatments) } \\
\hline Oxadiargyl 100g/ha (PE) & 3804 & 4718 & 77.5 & 8.1 & 4.8 & 1.32 \\
\hline Pretilachlor $1000 \mathrm{~g} / \mathrm{ha}(\mathrm{PE})$ & 3475 & 4303 & 76.7 & 8 & 4.7 & 1.19 \\
\hline $\begin{array}{l}\text { Oxadiargyl } 100 \mathrm{~g} / \mathrm{ha} \text { (PE) } f b \text { bispyribac-Na } \\
25 \mathrm{~g} / \mathrm{ha}(25 \mathrm{DAT})\end{array}$ & 4376 & 5440 & 79.4 & 8.2 & 4.9 & 1.46 \\
\hline $\begin{array}{l}\text { Pretilachlor } 1000 \mathrm{~g} / \mathrm{ha} \text { (PE) } f b \text { bispyribac- } \\
\mathrm{Na} 25 \mathrm{~g} / \mathrm{ha}(25 \mathrm{DAT})\end{array}$ & 4196 & 5213 & 78.4 & 8.2 & 4.9 & 1.38 \\
\hline Weed free & 4516 & 5506 & 80.2 & 8.5 & 5.1 & 1.28 \\
\hline Weedy & 3151 & 3895 & 74.6 & 7.6 & 4.4 & 1.15 \\
\hline $\mathrm{SEm} \pm$ & 83 & 105 & 0.6 & 0.1 & 0.07 & \\
\hline $\mathrm{CD}$ at $5 \%$ & 238 & 302 & 1.8 & 0.3 & 0.2 & \\
\hline
\end{tabular}

tistically at par to July $5\left(871 \mathrm{~g} / \mathrm{m}^{2}\right)$ planting, produced significantly higher crop dry matter than delayed planting (July 25 and August 15). Weed free treatment recorded highest crop dry matter accumulation at harvest $(964 \mathrm{~g} / \mathrm{m} 2)$ and it was at par to the application of oxadiargyl followed by bispyribac-sodium $(953 \mathrm{~g} / \mathrm{m} 2)$ and pretilachlor followed by bispyribac-sodium (914 g/ $\mathrm{m} 2$ ). The lowest values of the growth parameters viz. plant height, number of tillers per square meter, crop dry matter accumulation of rice were recorded with unweeded check. Present studies on weed in basmati rice are also confirmed by Heisnam et al (2015).

Yield attributes and yield: Early transplanting (June 15 and July 5) produced significantly higher number of effective tillers $/ \mathrm{m}^{2}$ along with higher number of filled grain/panicle than delayed planting (July 25 and August 15). The 1000-grain weight was not affected by time of transplanting. The highest grain yield (4346 $\mathrm{kg} / \mathrm{ha}$ ) was recorded under June 15 transplanting which was statistically at par with the grain yield $(4058 \mathrm{~kg} /$ ha) obtained under July 5 transplanting but both these transplanting dates gave significantly higher yield than delayed planting on August 15 (3289 kg/ha). Delayed planting (July 25 and August 15) produced significantly lower straw yield than timely planting (June 15 and July 5). These results of different yield attributes (effective tillers, filled grain/ panicle, test- weight and yield) in rice variety are in conformity with those of Chopra et al. (2006).

The highest numbers of effective tillers $/ \mathrm{m}^{2}$, grains length, total grains, filled grains/panicle with lowest numbers of unfilled grains/panicle were recorded in weed free check which were comparable to preemergence application of oxadiargyl followed by bispyribac-sodium applied and pretilachlor followed by bispyribac-sodium applied. The lowest values of all the above yield attributing characters were recorded with unweeded check. The highest effective tillers $/ \mathrm{m}^{2}$ $\left(262 / \mathrm{m}^{2}\right)$ were registered with pre-emergence application of oxadiargyl followed by bispyribac-sodium applied which were comparable to pre-emergence application of pretilachlor followed by bispyribac-sodium applied $\left(258 / \mathrm{m}^{2}\right)$. The lowest grain and straw yields as well as effective tillers $/ \mathrm{m}^{2}$ were recorded with unweeded check. The highest grain and straw yield in rice variety (Pusa Basmati 1509) recorded in weed free check which was comparable to pre-emergence application of oxadiargyl followed by bispyribac-sodium applied and pretilachlor followed by bispyribacsodium. These results of yield and its attributing characters are also confirmed by Singh and Paikra (2014).

Quality parameters: Delayed transplanting on August 15 did not improve hulling percentage significantly than earlier transplanting. Grain length was highest in the June $15(8.3 \mathrm{~mm})$ transplanting but decreased nonsignificantly with delayed in transplanting to July 5 (8.2 $\mathrm{mm})$, July $25(8.1 \mathrm{~mm})$ and August $15(8.0 \mathrm{~mm})$. Length breadth ratio in June 15 (4.9) and July 5 (4.9) transplanting was non-significantly higher than July 25 (4.8) and August 15 (4.7) transplanting. These finding in basmati rice are in close agreement with those of Chopra et al. (2006).

The highest hulling percentage was obtained under weed free plot $(80.2 \%)$ which was at par to application of oxadiargyl followed by bispyribac-sodium (79.4\%) and pretilachlor followed by bispyribac-sodium $(78.4 \%)$. Weed free plots recorded significantly highest grain length $(8.5 \mathrm{~mm})$ which was at par to oxadiargyl followed by bispyribac-sodium $(8.2 \mathrm{~mm})$ and pretilachlor followed by bispyribac-sodium. Highest LB ratio was obtained under weed free plot $(5.1: 1)$ which was statistically at par to application of oxadiargyl 
followed by bispyribac-sodium (4.9) and these were also at par to their individual applications of oxadiargyl and pretilachlor. Significantly lowest LB ratio found in rice variety under weedy check plot (4.4:1). Results of different parameter viz., Hulling percentage, grain length and lengh breadth ratio in basmati rice are in agreement with the work of Singh et al. (2007).

\section{Conclusion}

From the results of the present field experiment on response of basmati rice variety (Pusa basmati 1509) to time of transplanting conducted during Kharif 2014, it can be concluded that transplanting of basmati rice from June 15 to July 5 is optimum as it not only gave significantly higher grain yield $\left(4346 \mathrm{~kg} \mathrm{ha}^{-1}\right)$ but also fetched additional income (B:C ratio-1.43) than late planting (August 15). Among the weed control treatments, the highest grain yield (4376 $\mathrm{kg} \mathrm{ha}^{-1}$ ) and economic returns (B:C ratio-1.46) were found in pre-emergence application of oxadiargyl followed by bispyirbac-sodium applied at 25 DAT.

\section{REFERENCES}

Anonymous (2014a). Annual Progress Report, All India Coordinated Rice improvement programme, Indian Institute of Rice Research (ICAR), Hyderabad, 3:4.1144.117.

Anonymous (2014b). Agricultural statistics at a glance. De- partment of Agriculture, Cooperation \& Farmers Welfare. Ministry of Agriculture, Government of India.

Chopra, N.X., Chopra, Nisha and Yadav, R.N. (2006). Effect of transplanting dates on seed yield and quality of paddy cv. Pusa-44. Seed Res., 94(2):288-290.

Heisnam, P., Moiranthem, A., Keisham, A., Singh, N.I., Singh, A.H. and Singh, L. N. (2015). Efficacy of some promising weedicides on shallowland Transplanted rice (oryza sativa L.) Under rainfed Conditions. The Bio., 10 (1): 459-463.

Rajkhowa, D.J., Deka, N.C., Borah, N. and Barua, I.C. (2007). Effect of herbicides with or without paddy weeder on weeds in transplanted summer rice (Oryza sativa). Indian J. Agron., 52(3):107-110.

Sharma, Neeraj, Singh, Naveen, Singh, Mandeep and Bharaj, T.S. (2008). Quality characterstics of aromatic fine grained rice (oryza sativa) genotype for utilization in basmati improvement. Indian J. Agric. Sci.,78(1):42-49.

Singh, I., Ram, M. and Nandal, D.P. (2007). Efficacy of new herbicides for weed control in transplanted rice under rice-wheat cropping system. Indian J. Weed Sci., 39 (1\&2): 28-31.

Singh, M. and Paikra P.R. (2014). Bio-efficacy of postemergence herbicides in transplanted rice of chhattisgarh plains. The Bio., 9(3): 973-976.

Steel, R.G.D., Torrie, J.H., (1980). Principles and Procedures of Statistics. McGraw Hill Book Co. Inc., New York.

Subramanyam, D., Reddy, D.S. and Reddy, C.R. (2007). Influence of integrated weed management practices on growth and yield of transplanted rice (Oryza sativa). Crop Res., 34(1\&2): 1-5. 